\title{
Influence of IL2RA rs2104286 Polymorphism in the Risk of Biopsy-proven Giant Cell Arteritis
}

\author{
LUIS RODRÍGUEZ-RODRÍGUEZ, SANTOS CASTAÑEDA, TOMÁS R. VÁZQUEZ-RODRÍGUEZ, \\ INMACULADA C. MORADO, BEATRIZ MARÍ-ALFONSO, CARMEN GÓMEZ-VAQUERO, \\ JOSÉ A. MIRANDA-FILLOY, NORBERTO ORTEGO-CENTENO, JAVIER NARVAEZ, RICARDO BLANCO, \\ BENJAMÍN FERNÁNDEZ-GUTIÉRREZ, JAVIER MARTÍN, and MIGUEL A. GONZÁLEZ-GAY
}

\begin{abstract}
Objective. To assess the influence of the IL2RA rs $2104286 \mathrm{~A}>\mathrm{G}$ polymorphism on susceptibility to and clinical spectrum of manifestations of biopsy-proven giant cell arteritis (GCA).

Methods. Our study included 318 patients with biopsy-proven GCA. DNA from patients and healthy controls was obtained from peripheral blood. Samples were genotyped for the IL2RA rs2104286 A>G polymorphism using a predesigned TaqMan allele discrimination assay and by PCR amplification. Results. Although GCA patients showed a higher frequency of the minor allele homozygote of IL2RA rs 2104286 (GG) compared to controls $(5.1 \%$ vs $2.8 \%$, respectively; $\mathrm{p}=0.06$, odds ratio 1.84 , 95\% confidence interval $0.91-3.70$ ), the allele distribution showed no significant differences between GCA patients and controls. Stratification of GCA patients according to sex or polymyalgia rheumatica, jaw claudication, visual ischemic manifestations, or other severe ischemic complications did not yield significant differences in the allele or genotype frequencies of the IL2RA rs2104286 polymorphism.

Conclusion. IL2RA rs2104286 polymorphism does not appear to be a genetic risk factor for susceptibility to biopsy-proven GCA. Also, this polymorphism does not seem to be implicated in the clinical expression of this vasculitis. (First Release September 1 2010; J Rheumatol 2010;37:2331-3; doi:3899/jrheum.100388)
\end{abstract}

\author{
Key Indexing Terms: \\ GIANT CELL ARTERITIS \\ IL2RA GENE POLYMORPHISM
}

\section{GENETICS rs2104286}

From Instituto de Parasitología y Biomedicina López-Neyra, C.S.I.C., Granada; Department of Rheumatology, Hospital Clinico San Carlos; Department of Rheumatology, Hospital de la Princesa, Madrid; Department of Rheumatology, Hospital Xeral-Calde, Lugo; Department of Internal Medicine, Corporació Sanitaria Parc Taulí, Instituto Universitario Parc Tauli, UAB, Sabadell; Department of Rheumatology, Hospital Universitario de Bellvitge-IDIBELL, L'Hospitalet de Llobregat, Barcelona; Department of Internal Medicine, Hospital Clínico San Cecílio, Granada; and Department of Rheumatology, Hospital Universitario Marqués de Valdecilla, IFIMAV, Santander, Spain. L. Rodríguez-Rodríguez, MD, Instituto de Parasitología y Biomedicina López-Neyra, C.S.I.C., Granada, and Department of Rheumatology, Hospital Clinico San Carlos; S. Castañeda, MD, PhD, Department of Rheumatology, Hospital de la Princesa; T.R. Vázquez-Rodríguez, MD; J.A. Miranda-Filloy, MD, Department of Rheumatology, Hospital Xeral-Calde; I.C. Morado, MD; B. Fernández-Gutiérrez, MD, PhD, Department of Rheumatology, Hospital Clinico San Carlos;

B. Marí-Alfonso, MD, Department of Internal Medicine, Corporació Sanitaria Parc Tauli, Instituto Universitario Parc Taulí;

C. Gómez-Vaquero, MD, PhD; J. Narvaez, MD, PhD, Department of Rheumatology, Hospital Universitario de Bellvitge-IDIBELL, L'Hospitalet de Llobregat; N. Ortego-Centeno, MD, PhD, Department of Internal Medicine, Hospital Clínico San Cecílio; J. Martin, MD, PhD, Instituto de Parasitología y Biomedicina López-Neyra, C.S.I.C.; R. Blanco, MD, PhD; M.A. González-Gay, MD, PhD, Department of Rheumatology, Hospital Universitario Marqués de Valdecilla, IFIMAV.

Dr. González-Gay and Dr. Martín shared senior authorship in this study.

Address correspondence to Dr. M.A. González-Gay, Rheumatology Service, Hospital Universitario Marqués de Valdecilla, IFIMAV,

Avda. de Valdecilla, s/n, 39008 Santander, Spain.

E-mail:miguelaggay@hotmail.com

Accepted for publication June 10, 2010
Giant cell arteritis (GCA) is an inflammatory vasculopathy affecting medium-size and large arteries, with inflammatory lesions extending throughout all layers of the arterial wall. Vascular infiltrate is composed of T cells (the dominant cell population), highly activated macrophages and, in some cases, multinucleated giant cells ${ }^{1}$. CD4 $\mathrm{T}$ cells undergo clonal proliferation, confirmed by the isolation of identical clones from separate and independent parts of the same artery, and from both temporal arteries of the same patient ${ }^{1}$. This phenomenon supports an antigen-specific trigger within the affected arteries that induces production of interleukin 2 (IL-2) and interferon- $\gamma^{1}$.

IL-2 has a central role for T cell responses, by controlling the magnitude of clonal expansion, development of effector cells, and subsequent contraction of antigen-specific $\mathrm{T}$ cells $^{2}$. Also, this cytokine plays a role in activation-induced cell death and in the regulatory $\mathrm{T}$ cell homeostasis ${ }^{2}$.

IL-2 receptor (IL-2R) is composed of 3 different subunit complexes, CD25, CD122, and CD132 ${ }^{3}$. CD25 is mostly limited to activated $\mathrm{T}$ cells, including regulatory $\mathrm{T}$ cells ${ }^{3}$.

IL2RA rs2104286 ( $\mathrm{A}>\mathrm{G})$ polymorphism has been associated with susceptibility to various autoimmune diseases, such as multiple sclerosis ${ }^{4,5}$, rheumatoid arthritis ${ }^{6}$, and type 1 diabetes $^{5}$. This polymorphism has shown no association with other autoimmune diseases such as systemic lupus eryPersonal non-commercial use only. The Journal of Rheumatology Copyright (C) 2010. All rights reserved. 
thematosus or antineutrophil cytoplasmic antibody-associated vasculitis ${ }^{7}$.

GCA is a complex polygenic disease in which more than 1 genetic locus is likely to contribute to disease susceptibility and severity ${ }^{8}$.

Taking these considerations together, the aim of our study was to assess the potential association between IL2RA rs2104286 polymorphism and GCA in a large series of patients with biopsy-proven disease. We also studied whether this polymorphism may be implicated in the clinical spectrum of manifestations of GCA.

\section{MATERIALS AND METHODS}

Patients. We recruited 318 Spanish patients who fulfilled the 1990 American College of Rheumatology classification criteria for $\mathrm{GCA}^{9}$. All patients had a positive temporal artery biopsy ${ }^{10}$. Subjects were from Departments of Rheumatology or Internal Medicine from 5 Spanish cities: Lugo, Madrid, L'Hospitalet de Llobregat, Sabadell, and Granada. A control population of 867 healthy controls from corresponding cities matched with GCA patients was also assessed. Approval from the local ethical committees and written informed consent from patients and controls were obtained.

Clinical manifestations including polymyalgia rheumatica, jaw claudication, visual ischemic manifestations, cerebrovascular accidents (including stroke and/or transient ischemic attacks), severe ischemic manifestations, and the presence of a "true" occlusive disease were assessed ${ }^{10,11,12}$.

Genotyping methods. DNA from patients and controls was obtained from peripheral blood, using standard methods. Samples were genotyped for IL2RA rs2104286 A > G polymorphism using a TaqMan 5' allele discrimination assay (Applied Biosystems, Foster City, CA, USA), following the manufacturer's specifications.

Statistical analysis. Power of the study was assessed using Quanto v1.2.3. We used the chi-square test and Fisher exact test for Hardy-Weinberg equilibrium and statistical analysis to compare allelic and genotypic distributions. Odds ratios (OR) and 95\% confidence intervals (CI) were calculated according to Woolf's method using the Statcalc program (Epi-Info 2002; US Centers for Disease Control, Atlanta, GA, USA).

\section{RESULTS}

Clinical features of patients with GCA are summarized in Table 1. No evidence of departure from Hardy-Weinberg equilibrium was observed in controls. The case:control ratio was $1: 2.7$. The power of our study to find a difference between GCA patients and controls with an estimated OR between 1.5 and 2.0 , a type I error rate of 0.05 , a dominant inheritance mode, and $0.0001 \%$ of population risk was 71\%-99\%.

Association of IL2RA rs2104286 polymorphism with GCA. Allele frequencies in controls were similar to those report$\mathrm{ed}^{6}$. We found a nonsignificant trend towards a higher frequency of homozygotes for the minor allele $\mathrm{G}$ among GCA patients compared to controls (GG in GCA patients $5.1 \%$ vs $2.8 \%$ in controls; $\mathrm{p}=0.06$, OR $1.84,95 \%$ CI $0.91-3.70$; Table 2). However, no significant differences were found in the allelic distribution between GCA patients and controls.

Genotype and allele frequencies of IL2RA rs2104286 polymorphism according to patients' clinical manifestations. No significant differences in the genotypic or allelic frequencies
Table 1. Main clinical features of 318 patients with biopsy-proven giant cell arteritis Data in parentheses are \% unless otherwise indicated.

\begin{tabular}{lc}
\hline Feature & Variable \\
\hline Age at diagnosis, yrs, median (IQR) & $75(70-79)$ \\
Women & $216(68)$ \\
Headache & $267(84)$ \\
Abnormal temporal artery on examination & $196(62)$ \\
Polymyalgia rheumatica & $151(48)$ \\
Jaw claudication & $130(41)$ \\
Visual ischemic manifestations* & $68(21)$ \\
Stroke & $14(4)$ \\
Severe ischemic manifestation** & $169(53)$ \\
True occlusive disease*** & $44(14)$ \\
\hline
\end{tabular}

* Transient visual loss including amaurosis fugax, permanent visual loss, diplopia. ** At least one of: visual manifestations, cerebrovascular accident (stroke and/or transient ischemic attacks), jaw claudication, limb claudication of recent onset. *** At least one of: permanent visual loss, stroke, limb claudication of recent onset.

Table 2. Genotype and allele frequencies of IL2RA rs2104286 polymorphism in healthy controls and patients with biopsy-proven GCA.

\begin{tabular}{lcccc}
\hline & $\begin{array}{c}\text { Controls, } \\
\mathrm{n}=867(\%)\end{array}$ & $\begin{array}{c}\text { GCA, } \\
\mathrm{n}=318(\%)\end{array}$ & $\mathrm{p}$ & OR $(95 \% \mathrm{CI})$ \\
\hline $\mathrm{AA}$ & $559(64.5)$ & $202(63.5)$ & & $1=$ reference \\
AG & $284(32.8)$ & $100(31.4)$ & 0.86 & $0.97(0.73-1.30)$ \\
GG & $24(2.8)$ & $16(5.1)$ & 0.06 & $1.84(0.91-3.70)$ \\
$\mathrm{AA}+\mathrm{AG}$ & $843(97.3)$ & $302(94.9)$ & & $1=$ reference \\
GG & $24(2.8)$ & $16(5.1)$ & 0.06 & $1.86(0.93-3.70)$ \\
$\mathrm{A}$ & $1402(80.9)$ & $504(79.2)$ & & $1=$ reference \\
G & $332(19.1)$ & $132(20.8)$ & 0.38 & $1.11(0.88-1.39)$ \\
\hline
\end{tabular}

were found when GCA patients were stratified according to sex or presence or absence of specific features of the disease (Table 3).

\section{DISCUSSION}

We examined for the first time the contribution of the IL2RA rs2104286 polymorphism to GCA susceptibility in a large series of histologically confirmed patients. However, our results do not confirm a role of the IL2RA rs2104286 polymorphism in susceptibility to GCA or in the clinical expression of this vasculitis. In this regard, only a nonsignificant increased frequency of homozygotes for the minor allele $\mathrm{G}$ among GCA patients compared to healthy controls was found.

IL2RA rs2104286 polymorphism has been associated with other autoimmune diseases, especially with multiple sclerosis $^{4,5}$. We aimed to establish the influence of this polymorphism in GCA because of the role that IL-2 has in CD4+ $\mathrm{T}$ cell regulation. Although IL-2 is dispensable for the generation of effective T cell-mediated immunity, several studies indicate that a failure in the production of $\mathrm{CD} 4+\mathrm{CD} 25+$ regulatory $\mathrm{T}$ cells is the underlying cause of autoimmunity Personal non-commercial use only. The Journal of Rheumatology Copyright (c) 2010. All rights reserved. 
Table 3. Minor allele G frequency (\%) of IL2RA rs2104286 polymorphism in GCA patients according to gender and the presence (With) or absence (Without) of specific clinical features of the disease.

\begin{tabular}{lcccc}
\hline Feature & With, $\%$ & Without, $\%$ & $\mathrm{p}$ & OR (95\% CI) \\
\hline Gender $^{\dagger}$ & 20.4 & 21.6 & 0.73 & $0.93(0.61-1.43)$ \\
Polymyalgia rheumatica & 21.5 & 20.2 & 0.68 & $1.08(0.73-1.62)$ \\
Jaw claudication & 21.5 & 20.3 & 0.71 & $1.08(0.72-1.62)$ \\
Visual ischemic manifestations* $^{*}$ & 19.1 & 21.3 & 0.58 & $0.87(0.53-1.44)$ \\
Stroke & 17.9 & 21.0 & 0.69 & $0.82(0.24-2.26)$ \\
Severe ischemic complications** & 21.9 & 19.6 & 0.47 & $1.15(0.77-1.72)$ \\
True occlusive disease*** & 21.6 & 20.7 & 0.85 & $1.06(0.59-1.88)$ \\
\hline
\end{tabular}

$\dagger$ With: females; Without: males. * Transient visual loss including amaurosis fugax, permanent visual loss, or diplopia. ** At least one of: visual manifestations, cerebrovascular accident (stroke and/or transient ischemic attacks), jaw claudication, or limb claudication of recent onset. *** At least one of: permanent visual loss, stroke, or limb claudication of recent onset.

in the absence of IL-2 ${ }^{13}$. In GCA patients, the peripheral blood count of CD4+CD25+ regulatory $\mathrm{T}$ cells is not significantly different from that observed in healthy subjects ${ }^{13}$.

IL2RA rs2104286 polymorphism has no effect on the percentage of $\mathrm{CD} 4+\mathrm{CD} 25+$ regulatory $\mathrm{T}$ or memory CD4+CD25+ T cells. However, it is associated with a lower percentage of CD4+ naive cells expressing CD25+ on the cell surface ${ }^{14}$; it is also associated with a lower proportion of CD69+CD4+ naive T cells that upregulate CD25 upon T cell activation ${ }^{14}$. As a consequence, it is possible that this polymorphism might cause decreased production of IL-2 ${ }^{14}$, which would impair CD4+CD25+ regulatory $\mathrm{T}$ cell function ${ }^{15}$, taking into account that these cells themselves do not secrete IL- $2^{2}$ and this cytokine seems to function as a T cell growth factor for them.

Our results do not confirm a mayor contribution of IL2RA rs2104286 polymorphism in GCA.

\section{REFERENCES}

1. Wagner AD, Bjornsson J, Bartley GB, Goronzy JJ, Weyand CM. Interferon-gamma-producing $\mathrm{T}$ cells in giant cell vasculitis represent a minority of tissue-infiltrating cells and are located distant from the site of pathology. Am J Pathol 1996;148:1925-33.

2. Malek TR. The biology of interleukin-2. Annu Rev Immunol 2008;26:453-79.

3. Minami Y, Kono T, Miyazaki T, Taniguchi T. The IL-2 receptor complex: its structure, function, and target genes. Annu Rev Immunol 1993;11:245-68.

4. Hafler DA, Compston A, Sawcer S, Lander ES, Daly MJ, De Jager PL, et al. Risk alleles for multiple sclerosis identified by a genomewide study. N Engl J Med 2007;357:851-62.

5. Maier LM, Lowe CE, Cooper J, Downes K, Anderson DE, Severson C, et al. IL2RA genetic heterogeneity in multiple sclerosis and type 1 diabetes susceptibility and soluble interleukin-2 receptor production. PLoS Genet 2009;5:e1000322.
6. Barton A, Thomson W, Ke X, Eyre S, Hinks A, Bowes J, et al. Rheumatoid arthritis susceptibility loci at chromosomes 10p15, 12q13 and 22q13. Nat Genet 2008;40:1156-9.

7. Carr EJ, Clatworthy MR, Lowe CE, La Todd JA, Wong A, Vyse TJ, et al. Contrasting genetic association of IL2RA with SLE and ANCA-associated vasculitis. BMC Med Genet 2009;10:22.

8. González-Gay MA, Amoli MM, Garcia-Porrua C, Ollier WE. Genetic markers of disease susceptibility and severity in giant cell arteritis and polymyalgia rheumatica. Semin Arthritis Rheum 2003;33:38-48.

9. Hunder GG, Bloch DA, Michel BA, Stevens MB, Arend WP, Calabrese LH, et al. The American College of Rheumatology 1990 criteria for the classification of giant cell arteritis. Arthritis Rheum 1990;33:1122-8.

10. Gonzalez-Gay MA, Barros S, Lopez-Diaz MJ, Garcia-Porrua C, Sanchez-Andrade A, Llorca J. Giant cell arteritis: disease patterns of clinical presentation in a series of 240 patients. Medicine Baltimore 2005;84:269-76.

11. Gonzalez-Gay MA, Lopez-Diaz MJ, Barros S, Garcia-Porrua C, Sanchez-Andrade A, Paz-Carreira J, et al. Giant cell arteritis: laboratory tests at the time of diagnosis in a series of 240 patients. Medicine Baltimore 2005;84:277-90.

12. Rueda B, Lopez-Nevot MA, Lopez-Diaz MJ, Garcia-Porrua C, Martin J, Gonzalez-Gay MA. A functional variant of vascular endothelial growth factor is associated with severe ischemic complications in giant cell arteritis. J Rheumatol 2005;32:1737-41.

13. Dejaco C, Duftner C, Klauser A, Schirmer M. Altered T-cell subtypes in spondyloarthritis, rheumatoid arthritis and polymyalgia rheumatica. Rheumatol Int 2010;30:297-303.

14. Dendrou CA, Plagnol V, Fung E, Yang JH, Downes K, Cooper JD, et al. Cell-specific protein phenotypes for the autoimmune locus IL2RA using a genotype-selectable human bioresource. Nat Genet 2009;41:1011-5.

15. Fontenot JD, Rasmussen JP, Gavin MA, Rudensky AY. A function for interleukin 2 in Foxp3-expressing regulatory T cells. Nat Immunol 2005;6:1142-51. 